\section{The Influence of Temperature on the Properties of $\mathrm{ZrW}_{2} \mathrm{O}_{8}$}

Sergey N. KULKOV - Tomsk State University, Institute of Strength Physics and Materials Science SB RAS, Russia - kulkov@ms.tsc.ru

ELENA S. DEDOVA - Tomsk State University, Institute of Strength Physics and Materials Science SB RAS, Russia - Isdedova@yandex.ru

FERnANDo PEDRAZA - University of La Rochelle, France - fpedraza@univ-Ir.fr JÁNos ERDÉLYI - University of Miskolc, Dep. of Ceramics and Silicate Engineering, Hungary erdelyijanos@hdsnet.hu

Received: 21. 06. 2014. - Érkezett: 2014. 06. 21. " http://dx.doi.org/10.14382/epitoanyag-jsbcm.2014.7

\begin{abstract}
A single-phase $\mathrm{ZrW}_{2} \mathrm{O}_{8}$ was prepared by the hydrothermal route via decomposition of $\mathrm{ZrW}_{2} \mathrm{O}_{7}\left(\mathrm{OH}_{1.5}, \mathrm{Cl}_{0.5}\right) \cdot 2 \mathrm{H}_{2} \mathrm{O}$ at $843 \mathrm{~K}$. TEM, in situ high-temperature XRD and TG-DTA analyses of the $\mathrm{ZrW}_{2} \mathrm{O}_{8}$ synthesized were performed. The morphology of the material was represented as elongated particles with an intrinsic block structure. The stability fields of $\mathrm{ZrW}_{2} \mathrm{O}_{8}$ were determined. The $\mathrm{ZrW}_{2} \mathrm{O}_{8}$ demonstrated a negative thermal expansion behavior from 298 to $1023 \mathrm{~K}$.

Keywords: Zirconium tungstate; Hydrothermal synthesis; Negative thermal expansion coefficient.
\end{abstract}

\section{Introduction}

Designing and developing highly-effective materials that remain stable under extreme conditions are among the primary tasks of modern materials science. One potential solution of this problem lies in the development of composite materials with an appropriate matrix and filler. The use of ceramics as a matrix is reasonable as they possess high mechanical strength, hardness and wear resistance while retaining its properties under high temperatures [1-6]. However, ceramics are known to display low toughness making them brittle enough for specific applications. Therefore, the introduction of internal stresses at the filler/matrix interface allows strengthening of the overall composite structure. Such internal stresses can be introduced through a filler that has a negative thermal expansion behavior (NTE) due to the opposite thermal expansion values of the source filler and matrix materials.

There is a class of materials with a negative thermal expansion behavior. More often than not, the contraction of such materials is small, anisotropic and appears in a narrow temperature range. In this respect, zirconium tungstate is a promising material due to a negative isotropic thermal expansion coefficient (CTE) $\alpha=-8.6 \cdot 10^{-6}$ $\mathrm{K}^{-1}$ within a wide temperature range from 0 to $1050 \mathrm{~K}$ [7].

The unique nature of its thermal behavior is explained by the presence of rigidly connected $\mathrm{ZrO}_{6}$ octahedrons and $\mathrm{WO}_{4}$ tetrahedrons in the structure which can rotate relative to one another at an angle of $\theta$ with increasing temperature, thereby initiating shrinkage of the material [8]. Variations in the volume concentration of zirconium tungstate would thus enable both to cause internal stresses in ceramic composites, and to make materials with a negative, positive or near zero thermal expansion.

It is known that the method of synthesis has an impact on material behavior under different influences, including an increase in temperature. The hydrothermal method allows for the synthesis of highly-homogeneous powders with small particle size. Zirconium tungstate synthesis using a hydrothermal
Elena Dedova

Graduated at the National Research Tomsk State University (Russia) in 2010. At present she is post-graduate student in Strength Physics and Materials Science SB RAS under the guidance Prof. Kulkov. Topic of her Ph.D. work is "Structure features and properties of tungstate zirconium and alloys $\mathrm{Al}-\mathrm{ZrW}_{2} \mathrm{O}_{8}{ }^{\prime}$. Elena Dedova is author and co-author of 25 articles.

Fernando Pedraza is a professor of Laboratoire des Sciences de l'Ingénieur pour l'Environnement in the Université de La Rochelle (France). At present he is the vice-president of Université de La Rochelle and responsible for the international relations. Prof. Fernando Pedraza is a well known expert of aeronautical materials including high temperature oxidation and corrosion of turbines and has several scientific publications in these fields.

János Erdélyi

Graduated at the Mechanical Engineering Faculty in University of Miskolc (Hungary) in 2004. At present he is assistant professor in the Inst. Dep. of Ceramics and Silicate Engineering under the guidance of Prof. Gömze. He prepared and successfully completed his Ph.D. thesis in 2013. Dr. Erdélyi is author and co-author of 22 articles.

Prof. Sergey N. Kulkov Prof. Kulkov is head of Department of Ceramics in the Institute of Strength Physics and Materials Science of the Russian Academy of Science since 1989. He has got scientific degrees „Doctor of Physics and Mathematical Sciences" in 1990. Since 1992 he's working as professor both in Tomsk State University and in Tomsk Polytechnic University. In 1997 he had a Soros Professor grant. His research works are represented in 5 books, more than 150 articles, 18 patents and many International Symposiums and Conferences. At present he is head of department "Theory of Strength and Mechanic of Solids", member of "The American Ceramic Society" of "The APMIInternational" and the DYM AT Society (France).

route is based on the decomposition of the precursor $\mathrm{ZrW}_{2} \mathrm{O}_{7}\left(\mathrm{OH}_{1.5}, \mathrm{Cl}_{0.5}\right) \cdot 2 \mathrm{H}_{2} \mathrm{O}$ at relatively low temperatures [9]. At present, there is nevertheless a lack of research on the properties of zirconium tungstate powder obtained using a hydrothermal route when heated. The objective of the work is to investigate the influence of temperature on the properties of $\mathrm{ZrW}_{2} \mathrm{O}_{8}$.

\section{Materials and experimental procedure}

As source components, $\mathrm{Na}_{2} \mathrm{WO}_{4} \cdot 2 \mathrm{H}_{2} \mathrm{O}$ (p.a.), $\mathrm{ZrOCl}_{2} \cdot 8 \mathrm{H}_{2} \mathrm{O}$ (puriss.) and $\mathrm{HCl}$ (puriss.) were used to make the precursor. Aqueous solutions of $\mathrm{Na}_{2} \mathrm{WO}_{4} \cdot 2 \mathrm{H}_{2} \mathrm{O}(0.5 \mathrm{~mol} / \mathrm{L}), \mathrm{ZrOCl}_{2} \cdot 8 \mathrm{H}_{2} \mathrm{O}$ $(0.25 \mathrm{~mol} / \mathrm{L}), \mathrm{HCl}(8 \mathrm{~mol} / \mathrm{L})$ were thoroughly mixed and moved to a Teflon-lined stainless steel autoclave. The hydrothermal reaction was conducted at $433 \mathrm{~K}$ for 36 hours. The product obtained was rinsed repeatedly with distilled water and dried at $383 \mathrm{~K}$. To synthesize a monophasic $\mathrm{ZrW}_{2} \mathrm{O}_{8}$ powder, the synthesized precursor was annealed at $843 \mathrm{~K}$ for an hour in air. The thermal conditions were chosen according to the results reported in [9]. High-temperature in situ XRD analyses of the powder were conducted using a Bruker D8 diffractometer with filtered $\mathrm{CuKa}$ radiation and conducted at the Boreskov Institute of Catalysis SB RAS. Particle form and size analyses were conducted with JEM-2100 transmission electron microscope (TEM). The particle distribution was determined using randomly-cross-section method on TEM photos. 


\section{Results and discussion}

After the overall synthesis, the observations of the morphology of zirconium tungstate using a transmission electron microscopy showed that $\mathrm{ZrW}_{2} \mathrm{O}_{8}$ powder consisted of elongated particles with an intrinsic blocky structure (Fig. 1). The average block size varied from $20 \mathrm{~nm}$ to $50 \mathrm{~nm}$. The distribution of elongated particles by size (longitudinal and lateral) had a unimodal nature. The average lateral size of the elongated particles was from $30 \mathrm{~nm}$ to $700 \mathrm{~nm}$, and the average longitudinal size varied from $0.5 \mu \mathrm{m}$ to $5.0 \mu \mathrm{m}$. The EDAX analysis demonstrated that the quantitative atom ratio $(\mathrm{O} \sim 60$ at.\%, $\mathrm{W} \sim 13$ at.\%, $\mathrm{Zr} \sim$ 27 at. $\% \pm 2 \%)$ in the material obtained corresponded to the stoichiometry of $\mathrm{ZrW}_{2} \mathrm{O}_{8}$ compound ( $\left.\mathrm{Zr}: \mathrm{W}=1: 2\right)$ [7]. The analysis of reflections observed in the micro-diffraction image indicates the formation of cubic structures.
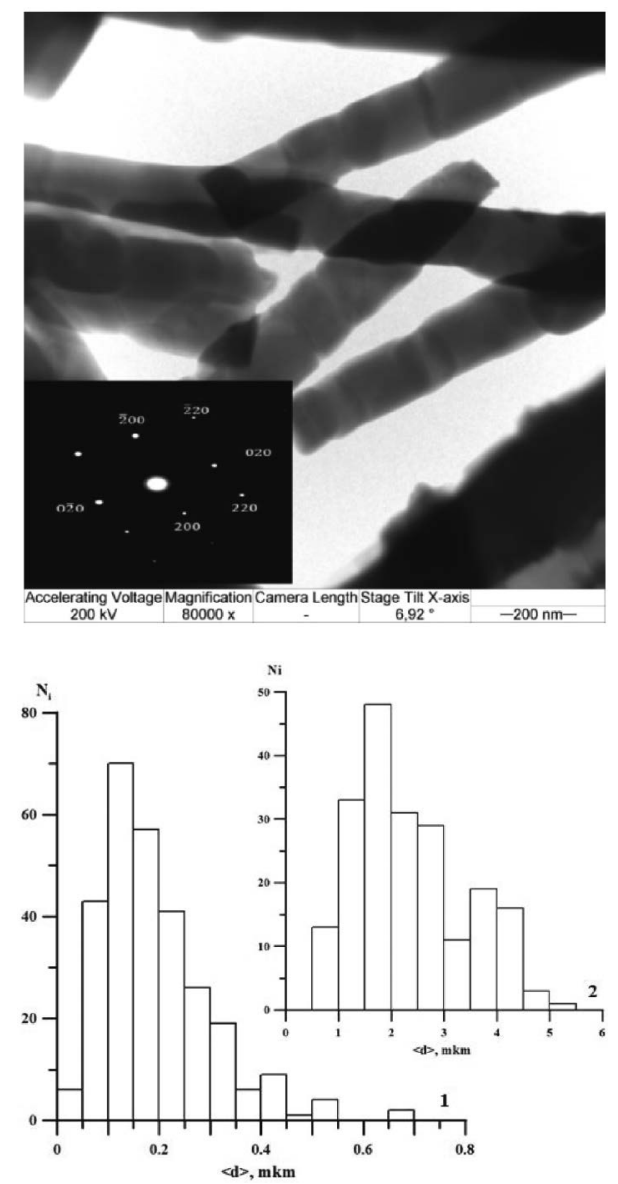

Fig. 1. TEM picture, microdifraction, particle distribution by lateral (1) and longitudinal (2) $\mathrm{ZrW}_{2} \mathrm{O}_{8}$ sizes

1. ábra A $\mathrm{ZrW}_{2} \mathrm{O}_{8} \mathrm{TEM}$ felvétel, mikrodiffrakció és

szemcseméret-eloszlás oldalirányban (1) és hosszirányban (2)

The investigations of phase transformation in a material at increasing temperature were performed in situ. The results of high-temperature in situ XRD observations are presented in Fig. 2. When $\mathrm{ZrW}_{2} \mathrm{O}_{8}$ is heated from room temperature to 423 $\mathrm{K}$, a gradual decrease in the reflection intensity is observed in XRD pattern from surfaces ( $\left.\begin{array}{lll}1 & 1 & 1\end{array}\right),\left(\begin{array}{lll}2 & 2 & 1\end{array}\right)$ and $\left(\begin{array}{lll}3 & 1 & 0\end{array}\right)$ up to its complete disappearance at temperatures beyond $473 \mathrm{~K}$. According to $[7,9,10]$, the disappearance of such peaks results from the transition from a low-temperature $\alpha-\mathrm{ZrW}_{2} \mathrm{O}_{8}$
$\left(P 2{ }_{1}^{3}\right)$ to a high-temperature modification $\beta-\mathrm{ZrW}_{2} \mathrm{O}_{8}(\mathrm{~Pa} 3)$ induced by an increase in symmetry of a space group. An increase to $873 \mathrm{~K}$ leads to the appearance of weak diffraction lines corresponding to tungsten oxide and zirconium oxide. A further increase in temperature to $1023 \mathrm{~K}$ led to an increase in the peak intensity of $\mathrm{WO}_{3}$, the appearance of $\mathrm{ZrO}_{2}$ lines and a decrease in $\mathrm{ZrW}_{2} \mathrm{O}_{8}$ reflections.

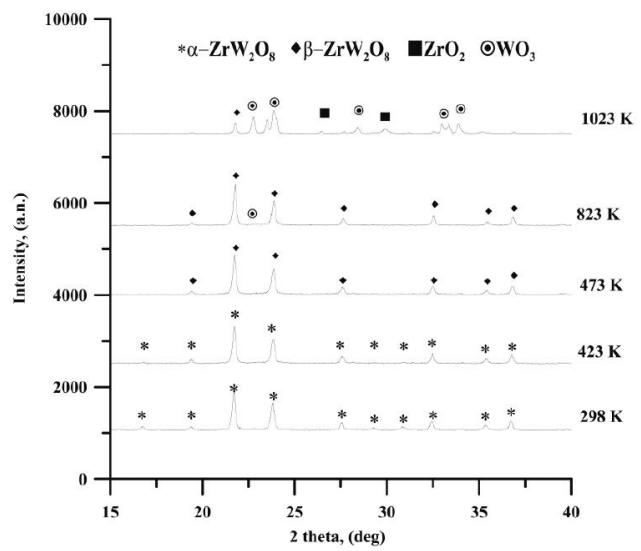

Fig. 2. The in situ high-temperature XRD pattern of $\mathrm{ZrW}_{2} \mathrm{O}_{8}$

2. ábra $\mathrm{A} \mathrm{ZrW}_{2} \mathrm{O}_{8}$ kerámia magas hömérsékletü in-situ röntgen-diffraktogramjai

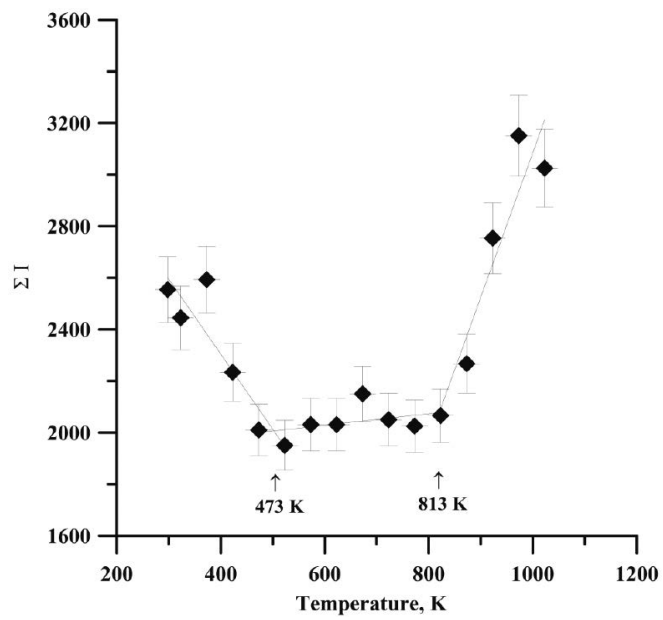

Fig. 3. The dependence between the temperature and the total intensity ( $(I)$ of all X-ray reflexes 3. ábra A valamennyi röntgen reflexió teljes intenzitása a hömérséklet függvényében

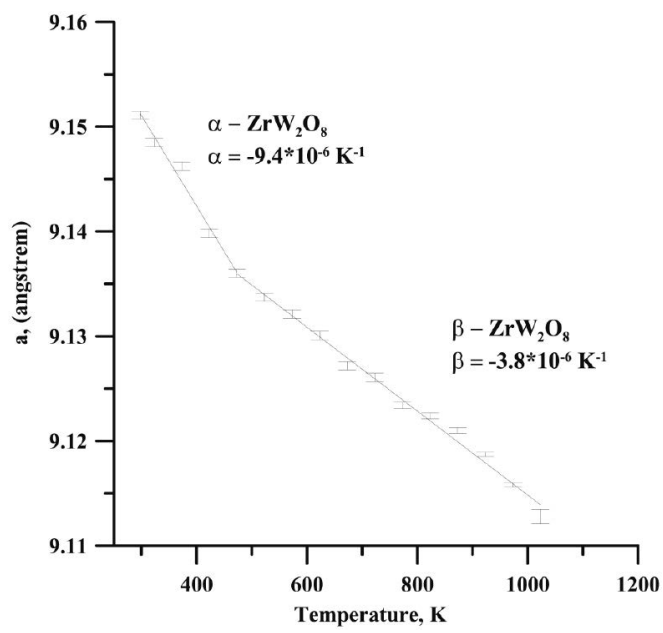

Fig. 4. The dependence between the temperature and the cubic lattice parameter of $\mathrm{ZrW}_{2} \mathrm{O}_{8}$ 4. ábra $\mathrm{A} \mathrm{ZrW}_{2} \mathrm{O}_{8}$ kerámia köbös rácsparaméterének változása a hömérséklet függvényében 
The dependence of the total intensity $\left(\sum \mathrm{I}\right)$ of all X-ray reflections on temperature, based on the results of XRD analysis, is shown in Fig. 3. The curve can be unambiguously divided into 3 stages. As the temperature increases to 473 $\mathrm{K}$, the total intensity decreases (stage 1 ). As the temperature increases from $473 \mathrm{~K}$ to $823 \mathrm{~K}$ (stage 2 ), the values of $\sum$ I vary within the margins of experimental error. A further increase in temperature to $1023 \mathrm{~K}$ (stage 3 ), results in an increase in the total reflex intensity. The inflexion points where the slopes changed corresponded to $473 \mathrm{~K}$ and $823 \mathrm{~K}$. According to the $\mathrm{X}$-ray diffraction data, the decline in the total intensity in stage 1 was initiated by an $\alpha \rightarrow \beta$ transition and, as a consequence, by the disappearance of some reflections. At stage 2 , there is only a high-temperature $\beta-\mathrm{ZrW}_{2} \mathrm{O}_{8}$. The increase in the total intensity at stage 3 can be explained by a pre-transitional phenomenon for forming new structures. Atoms in the zirconium tungstate structure begin to rearrange themselves in order to form sublattices of tungsten and zirconium oxides. Presumably, this movement of atoms precedes the decomposition of zirconium tungstate. It is known $[7,9,10,11]$ that zirconium tungstate loses its thermodynamic stability and decomposition into $\mathrm{ZrO}_{2}$ and $\mathrm{WO}_{3}$ occur at temperatures above $1050 \mathrm{~K}$. According to the XRD analyses, weak lines of $\mathrm{WO}_{3}$ and $\mathrm{ZrO}_{2}$ were observed on diffraction patterns above $873 \mathrm{~K}$. The intensity of the lines grew as the temperature is increased to $1023 \mathrm{~K}$ (Fig. 3).

The dependence of the cubic lattice parameter of $\mathrm{ZrW}_{2} \mathrm{O}_{8}$ on temperature is shown in Fig. 4. As seen in the graph, the lattice parameter decreased with an increase in temperature from 298 $\mathrm{K}$ to $1023 \mathrm{~K}$, indicating a negative thermal expansion. Two segments with different slopes in relation to the $\mathrm{x}$-axis can be outlined in the dependence. Changes in CTE occur at $473 \mathrm{~K}$, which corresponds to the $\alpha-\beta$ transition. For each segment, the coefficient of thermal expansion was calculated at the following values of temperature: $\alpha=-9.4 \cdot 10^{-6} \mathrm{~K}^{-1}$ from $298 \mathrm{~K}$ to $473 \mathrm{~K}, \alpha=-3.8 \cdot 10^{-6} \mathrm{~K}^{-1}$ from $473 \mathrm{~K}$ to $1023 \mathrm{~K}$.

\section{Conclusion}

This paper studied the influence of temperature on the properties of zirconium tungstate powder obtained using a hydrothermal route. It shows that $800 \mathrm{~K}$ is the limit until which zirconium tungstate retains its crystal structure. A subsequent increase in temperature is accompanied by changes in $\mathrm{ZrW}_{2} \mathrm{O}_{8}$ structure induced by the appearance of $\mathrm{WO}_{3}$ and $\mathrm{ZrO}_{2}$ phase nuclei which precedes the decomposition of $\mathrm{ZrW}_{2} \mathrm{O}_{8}$ into two constituent oxides at temperatures above $1000 \mathrm{~K}$. The phase transition from the low-temperature $(\alpha)$ to high-temperature $(\beta)$ modification of cubic zirconium tungstate occurs at $200^{\circ} \mathrm{C}$. The coefficients of thermal expansion of zirconium tungstate powder obtained using a hydrothermal route were: $-9.6 \cdot 10^{-6}$ $\mathrm{K}^{-1}$ for $\alpha-\mathrm{ZrW}_{2} \mathrm{O}_{8}$ and $-3.8 \cdot 10^{-6} \mathrm{~K}^{-1}$ for $\beta-\mathrm{ZrW}_{2} \mathrm{O}_{8}$.

\section{Acknowledgements}

This work was supported by the grants ISPMS SB RAS III.23.2.3. Authors thank Tatyana Yu. Kardash from Boreskov Institute of Catalysis SB RAS, shared use center "NANOTECH".

\section{References}

[1] Buyakova, S. P. - Promakhov, V. V. - Kulkov, S. N.: Thermal tests and their effect on the micro- and macrostructure of nanocrystalline $\mathrm{ZrO}_{2}$. Powder Metallurgy and Metal Ceramics. 2012, V. 54 (5-6), pp: 267- 272.

http://dx.doi.org/10.1007/s11106-012-9427-0

[2] Kocserha, I. - Gömze, A. L.: Friction properties of clay compounds. Applied Clay Science, 2010, V. 48 (3), pp. 425 - 430.

http://dx.doi.org/10.1016/j.clay.2010.01.017

[3] Gömze, A. L. - Gömze, L. N.: Alumina-based hetero-modulus ceramic composites with extreme dynamic strength - phase transformation of $\mathrm{Si}_{3} \mathrm{~N}_{4}$ during high speed collisions with metallic bodies. Épitöanyag. 2009/2. V 61 (2). http://dx.doi.org/10.14382/epitoanyag-jsbcm.2009.7

[4] Chu, H. L. - Wang, C. L. - Lee, H. E. - Sie, Y. Y. - Chen, R. S. - Hwang, W. S. - Wang, M. C.: Effect of sintering process parameters on the properties of 3Y-PSZ ceramics, 2013 IOP Conf. Ser.: Mater. Sci. Eng. 47012005 http://dx.doi.org/10.1088/1757-899X/47/1/012005

[5] Ainabayev, A. - Arkhipov, M. - Baideldinova, A. - Omarova, K. Ksandopulo, G.: Out-of-Furnace Synthesis of High-Temperature Ceramic Materials in the Revolving Reactor, 2013 IOP Conf. Ser: Mater. Sci. Eng. 47 012044 http://dx.doi.org/10.1088/1757-899X/47/1/012044

[6] Ershova, N. I. - Kelina, I. Yu.: High-temperature wear-resistant materials based on silicon nitride, Épitöanyag. 2009/2. V 61 (2). http://dx.doi.org/10.14382/epitoanyag-jsbcm.2009.6

[7] Mary, T. A. - Evans, J. S. O. - Vogt, T. - Sleight, A. W.: Negative Thermal Expansion from 0.3 to 1050 Kelvin in $\mathrm{ZrW}_{2} \mathrm{O}_{8}$. Science. 1996, V. 272, pp. 90-92. http://dx.doi.org/10.1126/science.272.5258.90

[8] Pryde, A. K. A. - Hammonds, K. D. - Dove, M. T. - Heine, V. - Gale, J. D. - Warren, M. C.: Origin of the negative thermal expansion in $\mathrm{ZrW}_{2} \mathrm{O}_{8}$ and $\mathrm{ZrV}_{2} \mathrm{O}_{7}$. J. Phys. Condens. Matter. 1996, V. 8, pp. 10973-10982. http://dx.doi.org/10.1088/0953-8984/8/50/023

[9] Kulkov, S. N. - Dedova, E. S. - Gubanov, A. I.: Investigation of phase transformation during the syntesis of zirconium tungstate. Russian Physics Journal. 2013, V. 56 (12/2), pp. 151-155.

[10] Evans, J. S. O. - David, W. I. F. - Sleight, A. W.: Structural investigation of the negative-thermal-expansion materials $\mathrm{ZrW}_{2} \mathrm{O}_{8}$. Acta Crystallographica. 1999, V. 330, pp. 333-340. http://dx.doi.org/10.1107/S0108768198016966

[11] Evans, J. S. O.: Negative thermal expansion materials. The Royal Society of Chemistry, Dalton Trans. 1999, pp. 3317-3326.

http://dx.doi.org/10.1039/A904297K

$\underline{\text { Ref.: }}$

Kulkov, S. N. - Dedova, E. S. - Pedraza, F. - Erdélyi, J.: Porosity and Mechanical Properties of Zirconium Ceramics Építőanyag - Journal of Silicate Based and Composite Materials, Vol. 66, No. 2 (2014), 35-37. p. http://dx.doi.org/10.14382/epitoanyag-jsbcm.2014.7

\section{A hőmérséklet hatása a $\mathrm{ZrW}_{2} \mathrm{O}_{8}$ kerámiák}

\section{tulajdonságaira}

A tanulmány nagytisztaságú $\mathrm{ZrW}_{2} \mathrm{O}_{8}$ kerámia vizsgálatával foglalkozik. Az egyfázisú $\mathrm{ZrW}_{2} \mathrm{O}_{8}$ kerámia, hidrotermális úton a $\mathrm{ZrW}_{2} \mathrm{O}_{7}\left(\mathrm{OH}_{1.5}, \mathrm{Cl}_{0.5}\right) \cdot 2 \mathrm{H}_{2} \mathrm{O}, 843 \mathrm{~K}$-en történố hôbontásával került elóállításra. A cirkónium-wolframátot TEM, TG-DTA valamint magas hômérsékletû in-situ XRD vizsgálattal jellemezték. Az anyag morfológiáját tekintve saját blokkstruktúrával rendelkezố jellegzetes megnyúlt szemcsékbốl áll. Meghatározásra került a kerámia stabilitási intervalluma valamint a hôtágulási együtthatója, mely a 298-1023 K közötti tartományon negatív elôjelú.

Kulcsszavak: cirkónium-volframát; hidrotermális szintézis; negatív hôtágulási együttható 